\title{
PERFECTION OF METHODS OF STUDIES OF THEORY OF RELATIVITY AND MODERN QUESTIONS OF PHYSICS IS ON BASIS OF DEVELOPMENT OF EMPIRIC THOUGHT ON EXAMPLE OF MEASURING OF THE GRAVITY FIELD
}

\section{ВДОСКОНАЛЕННЯ МЕТОДІВ НАВЧАННЯ ТЕОРІї ВІДНОСНОСТІ ТА СУЧАСНИХ ПИТАНЬ ФІЗИКИ НА ОСНОВІ РОЗВИТКУ ЕМПІРИЧНОГО МИСЛЕННЯ НА ПРИКЛАДІ ВИМІРЮВАННЯ ГРАВІТАЦИЙНОГО ПОЛЯ}

\author{
Anna Tomashevska ${ }^{1}$ \\ Iryna Salnyk ${ }^{2}$
}

DOI: https://doi.org/10.30525/978-9934-588-15-0-20

Abstract. The question of development of productive empiric thought of young people is considered. It is marked that a capacity for creative activity is to a great extent formed in school age. In the article the offered method of studies of theory of relativity, based on principles, which use the newest information from astrophysics, theory of gravitation, evolutionism Universe. It can be attained, in particular, on the example of study of questions about the methods of measuring gravity waves by the modern methods of research of space. On the basis of explanation of these principles development for the students of intellectual thought is rotined. The methods of research work and examples of the use of modern methods of cognition, which must be mastered yet during school studies, are rotined. It is marked that the sphere of researches in physics broadens constantly, engulfing all more difficult phenomena of nature. Underline, that a major role in this process belongs to school, studies in which must be inferior the idea of development of creative capabilities of students. It is rotined that one of basic terms of development of creative thought there is creation of atmosphere which is instrumental in appearance of new ideas. Providing of favourable atmosphere, goodwill

\footnotetext{
${ }^{1}$ Graduate Student of Department of Physics and Method of its Teaching,

Central Ukrainian State Pedagogical University named after Volodymyr Vynnychenko, Ukraine

${ }^{2}$ Doctor of Pedagogical Sciences, Associate Professor,

Central Ukrainian State Pedagogical University named after Volodymyr Vynnychenko, Ukraine
} 
from the side of teacher, development of curiosity, encouragement, to the utterance of original ideas, use of the personal example of creative approach a teacher, to the decision of problems - is the general methods of stimulation of creative activity. It is marked in the article, that during teaching of theory of relativity it is needed to underline that before was not examined, namely, that space must be probed on the basis of main ideas of new physics, such as: eventual or endless Universe, whether actual axioms of Euclid, what geometry space has, as mass influences on geomeriyu of space. In the XIX century of mathematics Bolyai and Lobachevskiy, Gaus and Riman, proved that it is possible to build other the geometry, which can be developed with a that mathematical strictness, that and evklidova. Same asserts the same general theory of relativity. Studying the theory of relativity is necessary on the basis of the newest achievements of modern ekserimental'noy physics, in particular on the experiment of measuring of gravity waves, to develop ekserimental'ne thought of students on this basis. It is marked that it is needed to explain to the students that before that how to become research, it is necessary to define research conception. It is necessary to rotin on an example measuring of gravity waves development of modern scientific thought and practical skills in the leadthrough of ekseriment.

\section{1. Ветуп}

Питання розвитку продуктивного мислення молоді слід розглядати як соціальне замовлення держави. Здатність до творчої діяльності, згідно психологічних досліджень, значною мірою формується у шкільному віці. Тому перед закладами шкільної освіти стоїть завдання розвитку продуктивного мислення учнів, як невід'ємної складової творчого потенціалу індивідуума.

Новизна дослідження полягає в вирішенні цих завдань на прикладі вивчення питань про методи вимірювання гравітаційних хвиль сучасними методами дослідження космосу, які є актуальними для сучасної фізричної науки.

Фізика, як навчальна дисципліна, має значні можливості розвитку продуктивного мислення суб'єктів навчання. Тому багато відомих методистів у своїх дослідженнях розглядали ряд аспектів цієї проблеми. Навички продукування інтелектуальних цінностей не формуються самі по собі, а розвиваються в результаті розумової активності 
школярів. Серед різних видів навчальної діяльності, що сприяють розвитку продуктивного мислення, однією 3 найефективніших вважається навчально-дослідницька. Мета дослідження - ознайомлення учнів 3 методами наукового пізнання, формування в них наукового світогляду на основі вивчення сучасних проблем експериментальної фізики, таких як вимірювання гравітаційного поля, вивчення еволюцію Всесвіту та ін.

Дослідницьке завдання полягає у формуванні вмінь застосовувати ті чи інші елементи методів наукового пізнання. Як свідчать спостереження та системні дослідження науковців, школярі, внаслідок недостатньої сформованості відповідних умінь, недостатньо орієнтуються у виборі методів наукових досліджень, які слід застосувати під час розв'язування тієї чи іншої дослідницької задачі. В результаті, вони зазнають труднощів у формулюванні гіпотези на підставі відомих фактів, не можуть запропонувати експеримент для підтвердження висунутої гіпотези.

Методологія полягає в озброєння учнів методологічними знаннями і є необхідною складовою гуманізації фізичної освіти. Логіка дослідження полягає в тому, що переважна більшість навчальних завдань дослідницького характеру спрямована на організацію емпіричної діяльності школярів. При цьому наявна лише незначна кількість завдань на організацію суто теоретичного дослідження. Такий дисбаланс не тільки не дозволяє учням із перевагою теоретичного стилю мислення реалізувати свої здібності під час навчального дослідження, а й суперечить логіко-гносеологічним, психологічним та методичним основам формування у них емпіричних і теоретичних знань з фізики. Використання спеціалізованих видань одночасно 3 підручниками також розширює можливості учнів в отриманні інформації, спонукає до порівняння та аналізу. Реалізація проблемного навчання, використання методів пошукового та дослідницького характеру, залучення учнів до експериментальної роботи є ефективним засобом активізації навчально-пізнавальної діяльності.

\section{2. Аналіз останніх досліджень і публікацій}

Проблема розвитку продуктивного мислення учнів $є$ настільки важливою та багатогранною, що стала предметом дослідження психології навчання з моменту іiї формування. Так, розумову діяльність школярів 
досліджували Вайтгеймер М., Моляко В.А., Тихомиров О.К., Тализіна Н.Ф. [14], Гальперін П.Я. [7], Калмикова 3.І. та ін. Серед науковців, що досліджували природу творчих здібностей, слід відмітити Богоявленську Д.Б. [3], Лернера І.Я. [10], Матюшкіна О.М. [11]. Ще в 1933 році педагог-новатор Джон Дьюі сказав, що «навчити людину мислити» $є$ головним завданням системи освіти [8].

Ряд відомих методистів фізики розглядали окремі аспекти цієї проблеми: Атаманчук П.С. [1] (управління навчально-пізнавальною діяльністю, спрямоване на розвиток творчої індивідуальності), Бойко М.П. (розвиток мислення учнів засобами технічної творчості), Будний Б.С. (формування фізичних понять), Разумовський В.Г. (розвиток творчих здібностей учнів), Ляшенко О.І. (формування та розвиток понятійного мислення), Малафєєв Р.І. (розвиток мислення засобами проблемного навчання), Павленко А.І. (розвиток мислення у процесі розв'язування фізичних задач), Сергєєв О.В. (наукове прогнозування та розвиток інтуїції при розв'язуванні творчих задач), Тарасов Л.В. (гармонійний розвиток логічного та інтуїтивного мислення). Дидактичні засади впровадження навчального дослідження у практику навчання фізики розроблялись Галатюком Ю.М. [6], Жуком Ю.О., Котельниковим Г.О., Тищуком B.I., Шутом М.I. [15] та іншими. Вивченням питань організації навчального дослідження займались відомі методисти, такі як: Бугайов О.І. (аналіз наукових методів пізнання); Величко С.П., Коршак С.В., Павленко А.І., Сусь Б.А., Шут М.I. [15] (методика навчальних експериментальних досліджень).

\section{3. Виділення не вирішених раніше частин загальної проблеми}

Під час викладання теорії відносності треба підкреслити те, що раніше не розглядалося, а саме, що простір необхідно досліджувати на основі головних ідей нової фізики, таких як: скінченний чи нескінченний Всесвіт, чи дійсні аксіоми Евкліда, яку геометрію має простір, як впливає маса на геомерію простору, які висновки випливають 3 експерименту Ейнштейна-Подольського-Розена, принципи квантово-механічного вимірювання Н. Бора і т.д. [18] Треба зазначити, що аксіоми Евкліда відносяться до математичної теорії геометричного характеру і представляють собою базис, який спочатку не ставився під сумнів. У XIX сторіччі математики Больяй і Лобачевський, Гаус 
і Ріман довели, що можна побудувати інші геометрії, які можуть бути розвинені з тією ж математичною строгістю, що і евклідова. Це ж саме стверджує і загальна теорія відносності [2]. Вивчати теорію відносності необхідно на основі новітніх досягнень сучасної ексериментальної фізики, зокрема на експерименті вимірювання гравітаційних хвиль, щоб розвинути ексериментальне мислення учнів на цій основі.

Головною метою статті є пояснення того факту, що геометрія, про яку йде мова в загальній теорії відносності, включає в себе не тільки геометрію тривимірного простору, а й чотиривимірне різноманіття простору і часу. Теорія відносності розкриває зв'язок між геометрією цього різноманіття і розподілом мас у Всесвіті. Треба пояснити учням, що перед тим як почати дослідження, необхідно визначити концеепцію дослідження. Необхідно показати на прикладі вимірювання гравітаційних хвиль розвиток сучасної наукової думки та практичних навичок у проведенні ексериментів.

\section{4. Приклад висунення концеції дслідження}

На даному етапі розвитку науки питання про те, яка геометрія $\epsilon$ справедливою стало емпіричним. Отже, теорія відносності піднімає по-новому питання простору і часу для дуже великих відстаней і припускає відповіді, які можуть бути перевірені спостереженнями. Астрономічні спостереження про розподіл спіральних туманностей дають інформацію про геометрію Всесвіту. На їх основі можна побудувати прийнятні моделі Всесвіту, наслідки яких можна порівнянти з емпіричними фактами [2]. Зараз деякі вчені вважають, що простір Всесвіту викривлений і може замикатися сам на себе [16]. Тому межу Всесвіту знайти неможливо, а розмір можна пов'язати з радіусом кривизни простору. Але якщо простір має радіус кривизни, можна говорити про його розширення і стиснення. Саме на цій основі трактується сучасною наукою Великий Вибух. Відстань між точками обчислюється як корінь квадратний із суми квадратів різниць відповідних координат. Ця формула некоректна, в ній втрачена залежність від часу. У цій формулі перед квадратним коренем повинна стояти функція $\mathrm{R}(\mathrm{t})$, яка пов'язана $з$ гравітацією. Функція R (t) змінюється дуже повільно, тому ми цього не помічаємо і замінюємо її константою. Однак, саме ця функція зумовлює еволюцію Всесвіту, тому що описує його розширення 
та стиснення. Відомі експерименти з вимірювань червоного зміщення свідчать, що R (t) - функція зростаюча, тобто простір повільно розширюється [13].

Якщо Всесвіт розширюється, то, можливо $\varepsilon_{0}$ i $\mu_{0}$ теж змінюються при зростанні відстанні $\mathrm{R}$, наприклад обернено пропорційно до $\mathrm{R}$, тоді

$$
\begin{gathered}
c(R)=\frac{1}{\sqrt{\frac{\varepsilon_{0} \mu_{0}}{R^{2}}}}=\frac{R}{\sqrt{\varepsilon_{0} \mu_{0}}} \\
\left.\left.\mathrm{v}=\sqrt{c^{2}\left(1-v^{2} / v_{0}^{2}\right.}\right)=c(R) \sqrt{\left(1-v^{2} / v_{0}^{2}\right.}\right)=\frac{R}{\sqrt{\varepsilon_{0} \mu_{0}}} \sqrt{\left(1-v^{2} / v_{0}^{2}\right)},
\end{gathered}
$$

де $\mathrm{v}$ - швидкість розбігання галактик, і маємо закон Хаббла.

Якщо припустити, що $\varepsilon_{0}$ i $\mu_{0} \rightarrow 0$, тоді $c \rightarrow \infty$ ? Можливо, що на границі Всесвіту $\varepsilon_{0}$ i $\mu_{0}$ зменшуються і внаслідок цього виникає червоне зміщення, бо швидкість світла зростає? Але це можна спостерігати лише ззовні, всередині простору еталонною $є$ швидкість світла, що вважається незмінною, при іiі зростанні зростає і відстань і час, а відношення $c=\frac{\lambda}{T}$ не зміниться. Тобто, змінюється тільки масштаб простору.

Відомо, що в експерименті Ейнштейна-Подольського-Розена (ЕПР) було показано, що дві частинки складають цілісну систему і, строго кажучи, в цю систему треба включати також вимірювальний прилад i взагалі весь Всесвіт [18].

Отже, Всесвіт являє собою єдине ціле, говорити про існування в ньому окремих частинок в певному сенсі проблематично. Історія фізики XX століття вчить нас, що провідними критеріями істинності теорії виступають iï формально-логічна бездоганність і підтвердження експериментом. До розгляду повинні бути прийняті як істинні - самі божевільні ідеї, якщо вони внутрішньо бездоганні і хоча б побічно експериментально підтверджені. Світ, у якому ми живемо, все більше відкривається нам як грандіозна логічна схема, а не звичний фізичний світ [9].

Досліджуючи ядерні взаємодії, Нільс Бор одним з перших сформулював принцип квантово-механічного вимірювання, яке відрізняєься від класичної схеми. Раніше вважалося, що завжди можна провести чітку межу, що відділяє вимірюваний об'єкт від приладу, оскільки в процесі вимірювання можна врахувати всі деталі впливу приладу на 
об’єкт. Але деталізація дії приладу на атомний об’єкт може бути здійснена лише з точністю до кванта дії. Д. Бом писав, що неможливо аналізувати окремі частини Всесвіту так, ніби кожна 3 них існує окремо. За його словами, вчені мають подібну до павутини глобальну структуру світу, де всі елементи взаємно узгоджені [4]. 3 цієї позиції Стапп інтерпритує вірогіднісний характер результатів вимірювань в квантовій фізиці.

Нова картина фізичної реальності, за думкою Бома, повинна базуватися на відносній локальності, яка залежить від цілого (Всесвіту) і на нединамічних відношеннях, які разом 3 динамічними визначають структуру світу. В картині світу Бома постулюється існування деякого невидимого порядку, внутрішньо притаманного системі космічних взаємовідносин, який організує всі інші види порядків у Всесвіті за аналогією з голограмою, в якій освітлення будь-якої ділянки дозволяє побачити все зображення вцілому. Спираючись на ідеї загальної теорії відносності про взаємозв'язок між масами і кривизною, Бом допускає можливість розсширення і узагальнення цих ідей в рамках гіпотези про топологічні властивості простору, скорельовані з типами порядку, що виникають у Всесвіті. Ця програма може бути розглянута в якості варіантів загального підходу до побудови фізичної картини світу, що використовує образ складної системи, що сама регулюється, де властивості iii елементів і частин обумовлені властивостями цілого, а ймовірна причинність виступає базисною характеристикою. Другим аспектом цієї системи виступає необоротна зміна і розвиток, що зв'язана $з$ появою нових рівнів організації і переходами від одного типу саморегуляції до іншого. Уява про такі системи включає в себе ідею динамічної рівноваги, але тільки в якості одного зі станів нерівноважних процесів, що характеризуються зміною типу динамичної рівноваги і переходами від одного типу до іншого. Стабільність виникає завдяки нерівноважним станам. В цих станах навіть невеликі флуктуації породжують аттрактори, що виводять до нової організації; «на всіх рівнях, будь то рівень макроскопічної фізики, рівень флуктуацій чи мікроскопічний рівень, джерелом порядку є неврівноваженість. Неврівноваженість це те, що народжує «порядок 3 хаосу» [12]. Отже, треба спробувати розкрити перед учнями сутність цих новітніх поглядів на простір і час $з$ допомогою сучасних методів дослідження. 


\section{5. Приклад вдосконалення методів навчання теорії відносності на основі розвитку емпіричного мислення}

Розглянемо розвиток емпіричного мислення на прикладах дослідження вченими гравіаційного поля на основі сучасних уявлень про Всесвіт.

Загальна теорія відносності, запропонована Ейнштейном, описує гравітацію як геометрію простору-часу. Масивні об'єкти, такі як зірки, «прогинають» простір, спотворюють геометрію простору-часу навколо себе. Якщо вони рухаються або взаємодіють 3 іншими об'єктами, виникають коливання - періодичні збурення простору навколо них. Гравітаційні хвилі - це брижі полотна простору-часу. Їх можна порівняти з брижами на поверхні ставка. Так, під час зіткнення двох чорних дір, брижі в просторі-часі будуть нести енергію 3 місця зіткнення зі швидкістю світла. Згідно з фізичними теоріями, будь-який масивний космічний об'єкт, який піддається прискоренню, повинен генерувати гравітаційні хвилі. Одне 3 реалістичних джерел гравітаційних хвиль, яке можна було б спостерігати - це чорні діри, що зіштовхуються. Це наймасивніші щільні об'єкти, які існують у Всесвіті. Їх зіткнення і злиття є найбільшими джерелами гравітаційних хвиль. Вважається, що гравітаційні хвилі генеруються оточенням чорних дір задовго до їх зіткнення. Гравітаційні хвилі також можуть бути викликані вибухом наднової та швидким рухом нейтронних зірок, що обертаються. Ще одне джерело - Великий вибух. Як же можна зафіксувати ці процеси?

В процесі розвитку астрономічних методик і модернізації технологій, астрономи почали вивчати різні довжини хвиль. Наприклад, рентгенівське випромінювання придатне для того, щоб побачити енергетичні події навколо чорних дір, інфрачервоне випромінювання допомагає бачити області зореутворення.

Пряме виявлення гравітаційних хвиль - це визначна подія, що може зрушити науку. При наявності достатньої кількості детекторів гравітаційних хвиль, вчені побачать об'єкти і явища, які залишаються прихованими від електромагнітного спектра. Дві чорні діри, що зливаються, не виробляють потужне електромагнітне випромінювання, а виробляють величезний гравітаційно-хвильовий сигнал. I, як і в електромагнітному спектрі, частота гравітаційних хвиль відображає природу явищ, які їх породжують. Отже, вимірювання гравітаційних хвиль можливе за аналогією з методом вимірювання електромагніт- 
них хвиль. Цим прикладом ми демонструємо принцип використання методу аналогії в процесі наукового дослідження. В результаті цих вимірювань, вчені змогли б створити гравітаційну карту найближчого Всесвіту зі списком перехідних подій (таких як виникнення наднових ) і $з$ фіксацією періодичних імпульсів від чорних дір. Дослідники вважають, що гравітаційно-хвильова астрономія могла б революціонізувати наше уявлення про Всесвіт. Будь-який об'єкт, що має масу, спотворює простір і може під час руху генерувати гравітаційні хвилі. Інша річ, що зареєструвати гравітаційні хвилі від легких об'єктів майже неможливо - гравітаційна взаємодія дуже слабка, вона слабкіша за електромагнітну на 40 порядків. Щоб створити хвилю, яку ми зможемо зареєструвати, нам бажано мати об'єкт з масою великої зірки, що рухається зі швидкістю, близькою до швидкості світла.Також можна зареєструвати «реліктові гравітаційні хвилі» - сліди народження Всесвіту, що започатковані компактною гарячою речовиною, яка швидко рухалася.

\section{6. Сучасні експерименти з вимірювання гравітаційних хвиль}

Починаючи з 1962 року, для реєстрації гравітаційних хвиль було побудовано кілька детекторів. Розкажемо учням про основні типи гравітаційних детекторів. Їх є два основних типи: резонансні - на гравітаційних антенах і інтерферометричні - на лазерних датчиках. Основний елемент резонансних детекторів - гравітаційна антенна, важка чавунна болванка, охолоджена до низької температури. При попаданні гравітаційної хвилі на болванку, розмір антени змінюється, i, якщо частота хвилі збігається з резонансною частотою антени, амплітуда коливань антени може стати настільки великою, що коливання можна детектувати. На цьому принципі працюють детектори MiniGRAIL, ALLEGRO, AURIGA, EXPLORER i NAUTILUS.

Iнтерферометричні детектори вимірюють зміну відстані між двома пробними масами за допомогою лазерного інтерферометра Майкельсона. У двох довгих (в кілька сотень метрів або навіть кілометрів), перпендикулярних одна одній вакуумних камерах підвішуються дзеркала. Лазерний промінь розщеплюється, йде вздовж камер, відбивається від дзеркал, повертається назад і знову з'єднується. У «спокійному» стані довжини підібрані так, що два промені після об'єднання в напівпрозорому дзеркалі гасяться (деструктивно інтерферують), i 
освітленість фотодетектора є нульовою. Якщь одне дзеркало змінить положення на мінімальну відстань, компенсація двох променів стане неповною і фотодетектор впіймає сигнал. Гравітаційні телескопи такого типу працюють в американо-австралійському проекті LIGO, німецько-англійському GEO600, японському TAMA-300 і франко-італійському VIRGO. Отже, підкреслимо це для кращого розуміння учнями, що в детекторах використовується принциип інтерферениії хвиль і принщип механічного резонансу.

У 2002 році обсерваторія LIGO приступила до безпосереднього пошуку гравітаційних хвиль. Відповідно до теорії, вони можуть бути виявлені у всіх частинах неба, вночі та вдень, в туманностях, зірках і поблизу планет. Вони без перешкод подорожують у космосі. LIGO складається з двох станцій спостереження, розташованих на відстані 3200 кілометрів одна від одної. Обидві станції ідентичні і мають два довгі вакуумні тунелі в формі букви L. Довжина кожного тунелю - 3,22 кілометри. В них розташовуються складні оптичні лабораторії, які використовують лазери для виявлення крихітних коливань, викликаних проходженням гравітаційної хвилі. Інструментарій LIGO здатний виявити найменші зміни. Будь-яка $з$ цих змін може вказувати на незначні викривлення простору $i$ часу. Якщо одна зі станцій виявляє крихітні коливання простору-часу, а інша ні, вчені вважають, що гравітаційні хвилі не виявлені: помилкові спрацьовування можливі навіть при сильних поривах вітру. І тільки якщо дві станції виявлять зміни, можна говорити про ймовірність проходження гравітаційної хвилі [17]. Отже, тут застосовується метод накопичення результатів спостереження, щоб не припустити випадкового спрацювання приладу.

В Італії, неподалік від Пізи, також побудовано пристрій Virgo (рис. 1). Обладнання для італійського експерименту включає два трикілометрові «плеча». Пристрій VIRGO надсилає лазерні промені по тунелях; гравітаційні хвилі мають втрутитись у рух потоків світла [17].

«Можливо, ми вперше маємо можливість виявити гравітаційні хвилі на Землі», - пояснює д-р Ф. Фрасконі з Пізанського університету, член міжнародної експериментальної групи, що працює з VIRGO [17].

«Технології, необхідні для виявлення гравітаційних хвиль, стали доступними лише сьогодні, - пояснює д-р Фрасконі. - В останні десять 


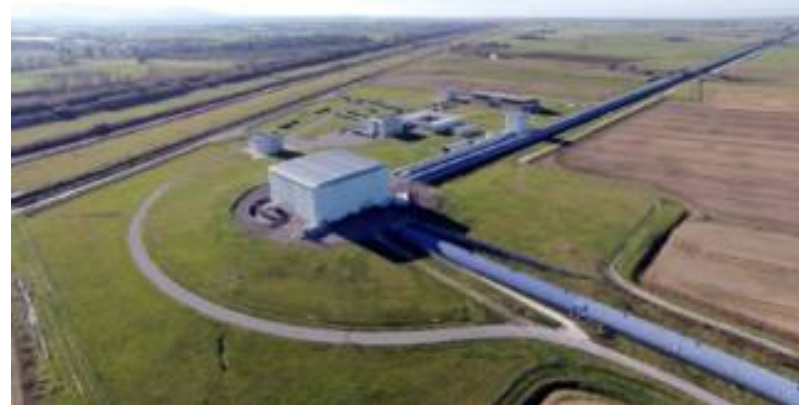

Рис. 1. Пристрій Virgo

Джерело: [17]

років ми розробили надзвичайно витончені технології, що дозволили побудувати саме такий інтерферометр».

Учені докладають максимум зусиль, аби захистити обладнання від будь-яких зовнішніх впливів, типових для життя на Землі, від транспортного шуму до землетрусу.

«Ми намагаємось побудувати прилад, куди не проникне жодний потенційний шум, - каже д-р Фрасконі. Найважливіше і найскладніше завдання-ізолювати дзеркала. Без цього нічого не вийде. Від початку було втрачено багато часу на розробку багатоетапного маятника, який би ізолював дзеркала від сейсмічного шуму» [19]. Тобто, було застосовано демпферування дзеркал. Але навіть якщо б в Італії і зловили сигнал, цього буде ще недостатньо, щоб робити остаточні висновки, удосконалений американський інтерферометр LIGO теж мусить зафіксувати сигнал. Потенційно це також може зробити інший пристрій у Німеччині.

Д-р Вайзмен з Імперського коледжу Лондона зазначає: «Виявлення гравітаційних хвиль - це найкраще підтвердження нашого розуміння загальної теорії відносності. Виявлення цих хвиль, крім того, дало б нам абсолютно новий інструмент для спостережень за деякими найцікавішими об'єктами у Всесвіті» [17].

У 2015 р. на прес-конференції міжнародного наукового консорціуму LIGO у Вашингтоні було зроблено заяву, що вченим вперше вдалося експериментально підтвердити існування гравітаційних хвиль. 
Група вчених з різних країн, що працюють у складі міжнародного проекту LIGO Scientific Collaboration, заявили, що за допомогою кількох обсерваторій-детекторів їм вдалося зафіксувати гравітаційні хвилі. Вони зробили аналіз даних, що поступили з двох лазерно-інтерферометричних гравітаційно-хвильових обсерваторій (Laser Interferometer Gravitational-Wave Observatory - LIGO), розташованих у США, а також з інших детекторів. Результати спостережень опубліковані у виданні Physical Review Letters. Гравітаційні хвилі було зареєстровано 14 вересня 2015 року в 5:51 ранку за літнім північноамериканським східним часом (12:51 за київським часом) на двох детекторах-близнюках обсерваторії LIGO, розташованих в Лівінгстоні (штат Луїзіана) і Хенфорді (штат Вашингтон), США. Детектори LIGO виявили відносні коливання величиною в $10^{-19}$ метрів пар пробних мас, рознесених на чотири кілометри. Збурення були викликані парою чорних дір (в 29 і 36 разів важчих за Сонце) в останні частки секунди перед їх злиттям в масивний обертовий гравітаційний об'єкт (в 62 рази важчий за Сонце). За частки секунди приблизно три сонячних маси перетворилися в гравітаційні хвилі, максимальна потужність випромінювання яких була приблизно в 50 разів більша, ніж від усього видимого Всесвіту. Злиття чорних дір відбулося 1,3 мільярди років тому (стільки часу гравітаційне збурення поширювалося до Землі). Отже, навіть такі далекі космічні об’єкти впливають на Землю, що підтверджує теорію про взаємозв'язок всіх об 'єктів Всесвіту. Коли хвилі досягли Землі, вони змістили промінь лазерного детектора на одну тисячну діаметра протона. Отримані коливання група вчених перетворила в звук. Сигнал має частоту, яка збігається з частотою людської мови. Крім того, слід зазначити, що в даному випадку команді LIGO пощастило. Як тільки вони включилися, вони зафіксували шуканий сигнал, тому що відбулася потрібна подія - злиття двох масивних чорних дір. В середньому, чорні діри в три, а то і в чотири рази легші, але в цьому випадку об'єкти виявилися дуже масивними, а тому сигнал вдалося зафіксувати з дуже великої відстані. Втім, удача приходить до того, хто на це заслуговує: проект LIGO - не просто дві L - подібні конструкції з 4-кілометровими «плечима», це - 25 років копіткої, наполегливої праці, витрати величезних коштів на дослідження, на створення нових технологій, на їх 
вдосконалення та розвиток, на виготовлення більш точних приладів [17]. Аналізуючи моменти приходу сигналів (детектор в Лівінгстоні записав подію на сім мілісекунд раніше за детектор в Хенфорді), вчені припустили, що джерело сигналу розташоване в південній півкулі. Обсерваторія LIGO фінансується Національним науковим фондом США і побудована внаслідок ініціативи американських фізиків Кіпа Торна і Рональда Дрівера. Дослідження в LIGO здійснюються в рамках однойменної колаборації більш ніж тисячею вчених з США i 14-ма іншими країнами, включаючи Росію, представлену двома групами з МГУ і Інститутом прикладної фізики Російської академії наук (Нижній Новгород). Московську групу створив і очолював Володимир Брагінський - один з піонерів гравітаційно-хвильових досліджень. До складу наукової групи, включеної в число співавторів наукового відкриття, входять сім співробітників кафедри фізики коливань МГУ, включаючи керівника колективу - Валерія Митрофанова. Група бере участь у проекті з 1992 року і займається підвищенням чутливості гравітаційно-хвильових детекторів і визначенням їх фундаментальних квантових і термодинамічних обмежень [5].

«Наукове значення цього відкриття величезне. Як і в випадку електромагнітних хвиль, ми усвідомимо його в повній мірі через деякий час», - зазначає Митрофанов [17].

Теоретичні та експериментальні дослідження фізиків з МГУ знайшли своє втілення під час створення детекторів нового покоління, що дозволили безпосередньо спостерігати гравітаційні хвилі від злиття двох чорних дір. В процесі роботи групи над проектом LIGO отримано результати, які важливі не тільки для пошуку гравітаційних хвиль, але й для фізики в цілому [17]. Цього відкриття фізики чекали сто років, з моменту проголошення положень загальної теорії відносності. Тепер стає можливим перевірити багато припущень космології, набагато краще зрозуміти будову і еволюиію Всесвіту [17].

Міжнародна група астрофізиків вважає, що цей перший доказ існування гравітаційних хвиль відкриє новий розділ в астрономічній науці. Це відкриття стало кульмінацією десятиліть спостережень і пошуків. Воно дозволить зрозуміти процеси у Всесвіті під час Великого вибуху. Професор Карстен Данцманн з Інституту гравітаційної фізики імені Макса Планка заявив, що виявлення цих хвиль $є$ найважливішим нау- 
ковим відкриттям з часу виявлення бозону Гіббса, його можна поставити поруч з відкриттям структури ДНК [17].

3 жовтня 2017 р. Нобілевський комітет назвав лауреатів з фізики 2017 року. Нобілевську премію отримали Райнер Вайс, Баррі К. Бариш і Кіп С. Торн за виявлення гравітаційних хвиль детектором LIGO. Церемонія нагороди лауреатів відбулася 9 грудня 2017 р. в Стокгольмі [18].

12 червня 2019 р. Володимир Путін нагородив лауреатів Державної премії РФ в сфері науки і технології: професора МГУ Валерія Митрофанова, академіка РАН Владислава Пустовойта і замісника директора 3 наукової роботи Інституту прикладної фізики РАН Юхима Хазанова за вклад в дослідження гравітаційних хвиль. Росія ввійшла в проект в числі перших учасників: керівник групи фізиків-гравітаційників з МГУ Володимир Брагинський в 1990-х познайомився з одним 3 засновників проекту, нобілевським лауреатом, Кіпом Торном, з яким в нього зав'язалось тісне співробітництво. Колаборація не могла зафіксувати сигнал через недостатню точність вимірювальної установки - лазерного інтерферометра. Саме рішенням цієї задачі і займались російські фізики. Вклад групи МГУ можна розділити на чотири складові. По-перше, фізики розробили спеціальні підвіси для дзеркал 3 плавленого кварцу. По-друге, запропонували методи, за допомогою яких стало можливим досягти стандартної квантової границі обчислень. По-третє, вчені розрахували граничну потужність лазера, за якої енергія оптичних резонаторів може передаватися дзеркалам лазерного інтерферометра, що складаються з 40 напилених шарів. По-четверте, фізики з МГУ розрахували шуми, які можуть виникати в лазерах. Такі розрахунки необхідні для відфільтрування гравітаційно-хвильового сигналу від шуму. Інший колектив російских учених, що входять в колаборацію LIGO - це група з Інституту прикладної фізики РАН 3 Нижнього Новгорода. Їх спеціалізація - лазери. Для гравітаційно-хвльового детектора вони розробили елементи, здатні пропускати майже $100 \%$ падаючих на них фотонів. Колектив третього лауреата Держпремії, академіка Владислава Пустовойта, вперше в світі опублікував наукову статтю, згідно з якою детектор гравітаційних хвиль потрібно робити по схемі інтерферометра, і обгрунтував такий підхід розрахунками. Стаття вийшла в 1962 році, а принципи, в ній викладені, були реалізовані в детекторі LIGO через декілька десятиліть [20]. 
В найближчих планах колаборації - збільшити потужність лазерів в установках з 200 кіловат до 1 Мегавату. Таке технологічне рішення дозволить зловити гравитаційно-хвильовий сигнал з «клаптика» Всесвіту об'єемом в 2,5 рази більше, ніж дозволяє нинішній детектор. Валерій Митрофанов відмічає, що 3 допомогою потужніх і чутливих детекторів буде можливо спостерігати події, що сталися майже одразу після утворення Всесвіту.

\section{7. Висновки і пропозиції}

ЗТВ - завершена фізична теорія. Це підтверджуює відкриття гравітаційних хвиль. Вона дає однозначні відповіді на фізично осмислені питання, а також дає чіткі передбачення для спостережень, що можна реально здійснити. Для цього потрібна копітка дослідницька робота та використання сучасних методів пізнання, які необхідно засвоїти ще під час шкільного навчання. Нарощування змісту і новизни матеріалу; надання учням свободи для виявлення своїх творчих можливостей; творче ставлення викладачів до викладання предмету, їх компетентність і авторитет дає вагомі результати у пошуках істини.

ЗТВ виникла в певному сенсі дуже рано, Ейнштейн обігнав час. Не менш важливою $є$ й та обставина, що дослідна база ЗТВ залишалася дуже вузькою, відповідні експерименти з ЗВТ $є$ надзвичайно важкі. Проте зараз ЗТВ та інші галузі фізики бурхливо розвиваються. Це результат величезного прогресу астрономічних спостережень, розвитку експериментальної техніки, вражаючого просування теорії.

В статті показано, як було створено концепцію дослідження, які теоретичні та практичні методи використовувалися під час дослідження.

Також показано розвиток сучасної наукової думки та практичних навичок у проведенні ексериментів.

Стаття демонструє як розкрити перед учнями сутність новітніх поглядів на простір і час з допомогою сучасних методів дослідження.

В статті показано, що вимірювання гравітаційних хвиль можливе за аналогією з методом вимірювання електромагнітних хвиль. Цим прикладом ми демонструємо принцип використання методу аналогії в процесі наукового дослідження.

В статті учням розкрито принцип дії основних типів гравітащійних детекторів. Їх є два типи: резонансні - на гравітаційних антенах і 
інтерферометричні - на лазерних датчиках. Показано, що інтерферометричні детектори вимірюють зміну відстані між двома пробними масами за допомогою лазерного інтерферометра Майкельсона.

Під час вимірювання гравітаційних хвиль застосовується метод накопичення результатів спостереження, щоб не припустити випадкового спрацювання приладів.

Під час вимірювання було розроблено багатоетапний маятник, який ізолював дзеркала від сейсмічного шуму [19]. Тобто, було застосовано демпферування дзеркал.

Експеримент виявив той факт, що навіть дуже далекі космічні об'єкти впливають на Землю, і це підтверджує теорію про взаємозв'язок всіх об'єктів Всесвіту.

Виявлення гравітаційних хвиль - це найкраще підтвердження нашого розуміння загальної теорї відносності. Виявлення цих хвиль, крім того, дало абсолютно новий інструмент для спостережень за деякими найцікавішими об'єктами у Всесвіті.

Сфера досліджень у фізиці постійно розширюється, охоплюючи дедалі складніші явища природи. Найважливіша роль у цьому процесі належить школі, навчання в якій має бути підпорядковане ідеї розвитку творчих здібностей учнів.

Однією з основних умов розвитку творчого мислення є створення атмосфери, яка сприяє появі нових ідей. Забезпечення сприятливої атмосфери, доброзичливість з боку вчителя, розвиток допитливості, заохочення до висловлювання оригінальних ідей, використання учителем особистого прикладу творчого підходу до вирішення проблем - $\epsilon$ загальними способами стимуляції творчої активності. Все це демонструє дана стаття.

\section{Список літератури:}

1. Атаманчук П.С. Управління процесом навчально-пізнавальної діяльності. Кам'янець-Подільський : Кам'янець-Подільський державний педагогічний інститут, 1997. $136 \mathrm{c}$.

2. Берков А.В., Кобзар І.Ю. Теорія тяжіння Ейнштейна. Загальні принципи та експериментальні слідства. Москва : МИФИ, 1989. № 151ж; Берков А.В., Кобзар I.Ю. Програми теорії тяжіння Ейнштейна до астрофізики та космології. Москва: МИФИ, 1990.

3. Богоявленская Д.Б., Петухова И.А. Умственные способности как компонент интеллектуальной активности. Психологические исследования интеллектуальной деятельности; под ред. О.К. Тихомирова. Москва : Наука, 1979. С. 17-28. 
4. Бом Д. Квантова теорія - vlabdownload.googlecode.com / files / Bom D. KVANTOVAYa TEORIYa (ru) (T) (732s). Djvu = Quantum Theory // New York: Prentice Hall. 1989 reprint, New York: Dover, ISBN 0-486-65969-0. 1951. С. 700, гл. 12, п. 15.

5. Брагинский В.Б., Манукин А.Б. Измерение малых сил в физических экспериментах. Москва : Наука, 1974. 151 с.

6. Галатюк Ю.М., Рибалко А.В. Керування пізнавальною діяльністю учнів за допомогою навчально-діагностичних завдань. Теорія $і$ методика навчання математики і фізики. Збірник наукових праць. Кривий Ріг : Видавн. відділ. Нау. МетАУ. Т. 2. 2002. С. 61-68.

7. Гальперин П.Я. О формировании умственных действий и понятий. Культурно-историческая психология. 2010. № 3. С. 111-114.

8. Д’юї Дж. Демократія і освіта. Львів : Літопис, 2003. 294 с.

9. Коган І.М. Прикладна теорія інформації. Москва : Радіо і зв'язок, 1981. 216 с.

10. Лернер И.Я. Проблемное обучение. Москва : Знание, 1974. 144 с.

11. Матюшкин А.М. Проблемные ситуации в мышлении и обучении. Москва : Педагогика, 1972. 208 с.

12. Николис Р., Пригожин И. Самоорганизация в неравновесных системах. Москва : Мир, 1976.

13. Попов С.Б., Топоренский А.В. Куда смещается красное смещение? Вселенная. Пространство. Время. NN2-3, 2014.

14. Талызина Н.Ф. Управление процессом усвоения знаний. Москва : Изд-во МГУ, 1984. 344 с.

15. Шут М.І., Сергієнко В.П. Науково-дослідна робота з фізики у середніх та вищих навчальних закладах : Навчальний посібник. Київ : Шкільний світ, 2004. $128 \mathrm{c}$.

16. Krasnikov S. (2014). Time machines with the compactly determined Cauchy horizon. Physical Review D. V. 90. 024067.

17. У пошуках хвиль, не знайдених Ейнштейном. Ребекка Морель Науковий кореспондент, BBC News 30 листопада 2015. URL: http://dalki-zori.com.ua/ category/novini/doslidzhenya-ta-vidkrittya

18. Ейнштейн А., Подільський Б., Розен Н. Чи можна вважати, що квантово-механічне опис фізичної реальності $є$ повним? URL: http://ufn.ru/ru/articles/1936/4/b

19. Нобелевская премия 2017 по физике - лауреаты. URL: http://twitter.com/ NobelPrize?lang=uk The Nobel Prize (@NobelPrize)

20. Forbes Media LLC. All Rights reserved. URL: https:/twitter.com/ NobelPrize?lang=uk tehnologii fizike

\section{References:}

1. Atamanchuk P.S. (1997). Upravlinnya procesom navchalno-piznavalnoyi diyalnosti [Management of the process of cognitive activity]. Kamyanec-podilskiy: Kamyanec-podilskiy state pedagogical college.

2. Berkov A.V., Kobzar I.Y. (1989). Teoriya tyazhinnya Eynshteyna. Zagalni pryncypy ta eksperymentalni slidstva [Theory of gravitation of Einstein. General principles and experimental consequences] no. 151zh / 
M., MIFI, 1989; Berkov A.V., Kobzar I.Y. Program the theory of gravitation of Einstein to astrophysics and cosmology. M.: MIFI.

3. Bogoyavlenskaya D.B. (1979). Umstvennye sposobnosti kak komponent intellektualnoy aktivnosti [Intellect capabilities as component of intellectual activity]. D.B. Bogoyavlenskaya, I.A. Petukhova. Psychological researches of intellectual activity; under red. O.K. Tikhomirova. M.: Science.

4. Bom D. (1951). Kvantova teoriya [Quantum Theory]. New York: Prentice Hall. 1989 reprint, New York: Dover, ISBN 0-486-65969-0. P. 700.

5. Braginskij V.B., Manukin A.B. (1974). Izmerenie malyh sil v fizicheskih eksperimentah [Measuring of small forces is in physical experiments]. M.: Science.

6. Galatyuk Yu.M., Rybalko A.V. (2002). Keruvannya piznavalnoyu diyalnistyu uchniv za dopomogoyu navchalno-diagnostychnyh zavdan [Management of students cognitive activity by educational-diagnostic tasks]. Theory and method of studies of mathematics and physics. Collection of scientific labours / Vidavn. department. Nau. METAU. T. 2. Pp. 61-68.

7. Galperin P.I. (2010). O formirovanii umstvennyh deystviy i ponyatiy [About forming of mental actions and concepts]. Cultural and historical psychology. № 3, pp. 111-114.

8. Dyuyi Dzh. (2003). Demokratiya i osvita [Democracy and education]. Lviv: Chronicle.

9. Kogan I.M. (1981). Prykladna teoriya informaciyi [The Applied information theory]. M.: Radio and zvyazok.

10. Lerner I.Y. (1974). Problemnoe obuchenie [Problem teaching]. M.: Knowledge.

11. Matyushkin A.M. (1972). Problemnye situacii v myshlenii i obuchenii [Problem situations in thought and teaching]. M.: Pedagogics.

12. Nikolis R., Prigozhin I. (1976). Samoorganizaciya v neravnovesnyh sistemah [Samoorganizaciya in the non-equilibrium systems]. M.: The World.

13. Popov S.B., Toporenskiy A.V. (2014). Kuda smeshhaetsya krasnoe smeshhenie? [Wear displaced redshift?]. The article is «Universe. Space. Time» of NN2-3.

14. Talyzina N.F. (1984). Upravlenie processom usvoeniya znaniy [Management by the process of mastering of knowledges]. M.: MGU.

15. Shut M.I., Sergienko V.P. (2004). Naukovo-doslidna robota z fizyky u serednih ta vyshhyh navchalnyh zakladah [Research work is from physics in middle and higher educational establishments]. K.: School world.

16. Krasnikov S. (2014). Time machines with the compactly determined Cauchy horizon. Physical Review D. V. 90. 024067.

17.In search of waves, not found Einstein. Rebekka Morel the Scientific correspondent, BBC News on November, 30 2015. URL: http://dalki-zori.com.ua/ category/novini/doslidzhenya-ta-vidkrittya

18. Eynshteyn A., Podilsky B., Rozen N. (1934). «Is it possible to consider that kvantovo-mekhanichne description of physical reality is complete?» URL: https:/ufn.ru/ru/articles/1936/4/b/

19. Nobelevskaya of premiya 2017 for fizike - laureaty. URL: http://twitter.com/ NobelPrize?lang=uk The Nobel Prize (@NobelPrize)

20. Forbes Media LLC. All Rights reserved. URL: https:/twitter.com/ NobelPrize?lang=uk tehnologii fizike 